\title{
Economic Consequences of Pension Accounting
}

\author{
Maria Iuliana Sandu ${ }^{1}$ \\ 1 The Bucharest Academy of Economic Studies, Bucharest, Romania \\ Correspondence: Maria Iuliana Sandu, The Bucharest Academy of Economic Studies, Piata Romana, No. 6, \\ Bucharest, Romania. Tel: 40-21-319-1900. E-mail: iuliana.sandu@cig.ase.ro
}

Received: April 22, 2012

Accepted: May 31, $2012 \quad$ Online Published: July 20, 2012

doi:10.5539/ibr.v5n8p172

URL: http://dx.doi.org/10.5539/ibr.v5n8p172

\begin{abstract}
The balancing act between neutral accounting policies and accounting policies that take economic consequences into consideration has been on the agenda of accounting regulators and researchers since the 70s. The transition to fair value accounting in conjunction with the recent economic crisis have led to a revival of interest in this balancing act especially in the field of pension accounting. Due to the negative economic consequences anticipated by companies sponsoring defined benefit pension funds (e.g., decrease in owners' equity), pension accounting has moved from an accounting that takes into consideration economic consequences to a more neutral accounting only gradually and not in a once-and-for-all event. This paper documents identified and anticipated economic consequences of recent pension accounting changes like shifts between different types of pension plans (from defined benefit to defined contribution), changes in the governance structure between the sponsoring organization and the pension fund (less accountability by pension fund), more incentives for earnings management, and changes in investments strategies by sponsoring organizations (from equity to bonds). Recent proposals for regulatory changes (i.e., IAS 19 revised) head towards an excessive conservatism and hence diminished neutrality. During and in the aftermath of the recent economic crisis - when interest rates are low conservative pension accounting can have negative economic consequences if pension funds look as if they are underfunded and sponsoring companies present higher retirement related expenses. Shifts in the accounting policies that depart from neutrality and have negative economic consequences should be taken into consideration by regulators when issuing accounting standards.
\end{abstract}

Keywords: pension plans, pension accounting, fair value, discount rates

\section{Introduction}

Economic consequences of accounting are "the impact of accounting reports on the decision making behavior of businesses, governments, unions, investors and creditors” (Zeff, 1978, p.56). Accounting information is useful for decision making when it has an impact on the decisions made. Therefore, accounting information is useful when it has economic consequences. In order for information to be useful for decision making it has to be reliable and hence neutral and verifiable. Neutral information does not favor particular groups and verifiable information requires objective mechanisms for measurement. But some accounting policy shifts may have severe economic consequences that are preferred to be avoided. When standard setters takes into consideration the possible economic consequences of accounting standards then the accounting information is not neutral anymore. Pension accounting is a typical example of such an issue.

As pensions went from being seen as gifts granted by employers to employees to being an obligation of the employer, accounting had to follow this change (Napier, 2009). In its first stages, accounting for pensions involved recognizing a cost as pensions were being paid. But when accounting standards (SFAS 87, 1985; IAS 19, 1983) were issued the pension cost approach was replaced by a pension liability approach. That is, companies had to account for the fact that working employees accrued pension rights during their active life. While salaries can be passed immediately as cash disbursements, the accrued pension rights constitute an obligation on the balance sheet of the employer. This obligation ends when the pension rights are paid to the retiring employees or to beneficiaries.

Accounting standards (i.e., IAS 19, SFAS 158) identify two types of pension plans, defined benefit pension plans (DBs) and defined contribution pension plans (DCs). The benefits that have to be paid when employees retire are liabilities for companies sponsoring pension funds. While companies that sponsor DCs settle their liabilities 
paying a third party to assume payment for pension benefits, DBs sponsoring companies settle their liabilities by paying the benefits themselves. DBs guarantee a certain final benefit and vary the contribution rate required from plan participants in order to match the benefit guaranteed. This type of plan places most of the risk, in its different shapes (i.e., market risk, longevity risk etc.) on the company. DCs require a fixed periodical contribution and make no guarantee with respect to the pension benefit. This construction places most of the risk on the pension plan participants, namely the employees of the company. Therefore, pension accounting for companies that sponsor DCs involves only registration of the periodic contribution paid to the pension fund while pension accounting for DBs requires assumptions about the future.

Because standard setters took into consideration the economic consequences of pension accounting the move from a cost approach to an accrual approach was only gradual. Full accrual recognition of pension expenses and liabilities was feared by sponsoring companies as such a move would have caused a significant decrease in the reported owner's equity (Carpenter \& Mahoney, 2004). The first pension accounting standards (SFAS 87, 1985; IAS 19, 1983) did not impose a complete shift towards a neutral pension accounting and allowed for smoothing mechanisms (i.e., corridor approach). According to Carpenter and Mahoney (2004) standard setters saw a need to depart from the principle of neutrality to avoid altering the performance of sponsoring companies and in this way the economy itself. Although much has been done in achieving neutrality of pension accounting information, recent proposed changes (i.e., use of the same interest rate for assets and liabilities) raise the question if economic consequences stem from neutrality or rather from misunderstandings of the complex assumptions that pension measurement involves.

This paper presents through simple examples the most important features of pension accounting and their potential economic consequences. Because pensions are long term products the magnitude of the economic consequences of recent pension accounting changes is yet unknown. For this reason the article documents economic consequences of recent pension accounting changes already identified but also anticipated effects. The economic consequences are presented in a framework that emphasizes the party they impact the most, shareholders or pension plan participants. Outlining the economic consequences of implemented or proposed changes in pension accounting is of importance as they can lead to many adverse situations like pauperism in society.

\section{Pension Valuation}

Employees accumulate pension rights for each additional year they work. Companies sponsoring DBs have to show this accumulation in the financial statements of the company. This incremental amount discounted to the present moment forms the service cost that is shown as a pension expense of the company. Further, because benefits are paid in the future they increase in time with an interest rate adding an interest cost to the present pension expenses of a company. On the asset side the investments in stocks and bonds bring dividends, interest and appreciation in value and all these increases cumulate in the so-called return on plan assets. Under the current accounting regulations (i.e., IAS 19, SFAS 158) the rates of return on assets are based on expectations on how investments are going to evolve over the life of the obligation. The service cost, the interest rate with which pension rights increase and the expected return on assets meet at the level of the profit and loss account - see Figure 1. The new pension rights accrued by employees discounted to present value form the service costs, the pension liability at the beginning of the period multiplied by the annual interest rate forms the interest cost. The investments grow with an expected rate of return, which decreases the pension expenses. The arrows in Figure 1 show the starting point of the computations which end in values included in the profit and loss account of the sponsoring company. The pension expenses increase with a service and an interest cost and decrease with the expected return on the plan assets.

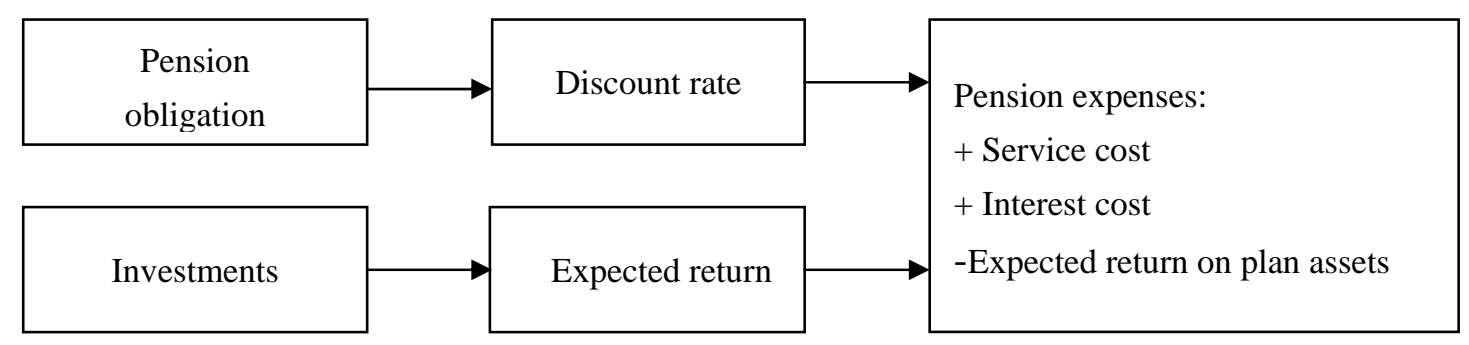

Figure 1. Pension expenses for DBs 
Determining the amount payable to employees upon retirement involves projecting the obligations into the future. Actuaries have the task of looking into the future and making assumptions about future productivity, future wage increase, future inflation and many other elements. Probably one of the most important assumptions is related to the expected remaining lifetime of employees as more longevity means more pension payments.

As pension liabilities are not traded in the market, their value depends on projected liabilities amounts and discount rates that bring these projected amounts into present accounts. Actuaries were responsible also for setting the discount rate that brought future values into the present but in the aftermath of the 2000 stock market crash, accounting regulatory bodies took an interest in better standardizing the discount rate used to find the present value of liabilities and mandated the actuarial discount rate to be replaced by market based yields (i.e., high quality corporate bond yields of a term consistent with the post-employment benefit obligation) in order for the liabilities to be valued fairly.

The accounting changes that encouraged fair valuation of pension liabilities implied looking at the market to find the correct discount factor and this led to discount curves - each maturity with its discount factor. Having different discount rates for different periods to maturity is a considerable change to the actuarial approach that used fixed discount rates irrespective of the maturity of the payment. As Table 1 illustrates, a fixed actuarial discount factor can underestimate the pension related expenses. Let Fund A and Fund M be two DBs that only differ with respect to the discount rate used. For Fund A an actuarial fixed interest rate of $4 \%$ is used and the service costs are €943. For Fund $\mathrm{M}$ the discount rate is retrieved from the market and it differs from one year to the other. The interest rate for the second year is specially chosen higher as interest rates for long term instruments are expected to be higher than those for shorter term instruments. In Fund M's case the service cost is $€ 952$. Compared to the situation with fixed $4 \%$ discount rate, the service cost of Fund $M$ is higher resulting in more expenses for the company. That is, the service cost determined under the fair value approach is higher than that determined under the actuarial approach showing that an actuarial discount rate underestimated the true pension costs of a company.

Table 1. Effect of fixed discount rate on pension expenses, for different maturities

\begin{tabular}{llll}
\hline Fund A & & Fund M & 2 \\
\hline Years to payment & 2 & Years to payment & 500 \\
Pension obligation year 1 & 500 & Pension obligation year 1 & 500 \\
Pension obligation year 2 & 500 & Pension obligation year 2 & $2 \%$ \\
Discount rate & $4 \%$ & Discount rate 1 & $4 \%$ \\
Service cost & 943 & Discount rate 2 & 952 \\
\hline
\end{tabular}

Discount rates that stem from the market have the advantage of incorporating risks (discount rates from riskier entities are higher than discount rates from default-free entities). Although accounting regulations indicate that liabilities should be discounted using high quality corporate bonds, the choice should be made according to the promise: if a sponsor guarantees for its employee's pension benefits then those benefits are riskless and should be discounted using a high quality bond yield. If the contract between the company and the employee has conditional promises such as "if the funding ratio drops below $90 \%$ then we are entitled to increase the required premiums", the discount rate should be higher than a high quality bond yield. The nature of the contract between the sponsoring organization and the employees should dictate the proper discount rate.

\section{Earnings Management}

\subsection{Discount Rates}

Accounting standards offer guidelines with respect to discount rates (i.e., IAS 19 - Employee Benefits mentions that high quality corporate bonds are to be used as discount rates but it does not indicate which exactly to choose) and thus allow for flexibility with respect to the choice of the discount factor. Because there is variety of market yields on fixed instruments, a choice between a high market yield and a low one, namely choice between a high discount rate and a lower one, can be the choice between low and high expenses. Earnings can be managed if high discount rates are chosen with the purpose of lowering the service cost and the interest cost (Adams, Frank, \& Perry, 2011). Fried (2010) documents the impact of SFAS 158 on the behavior of sponsoring companies and identifies that due to increased SFAS 158 related pension liabilities managers chose to use higher discount rates. Also Houmes and Boylan (2010) identifies the usage of higher discount rates after the enactment of SFAS 158 especially for sponsoring companies with decreased liquidity and increased leverage. 
Assuming that the problem of discount rates is settled, companies have another levy to increase or decrease pension expenses and to manage earnings to their advantage. Research has documented this behavior. According to Adams et al. (2011) using high expected rates of return can unjustly decrease expenses and inflate earnings showing a better financial situation of the company. Moreover, there is doubt on how the expectations related to the rates of return on the pension assets are obtained. Ramaswamy (2012) identifies that the median assumed return for US companies has been of 8.5 percent even though the yield on Treasury securities (i.e., the discount rate for pension liabilities) has been declining. SFAS 132(R) - Employers' Disclosures About Pensions and Other Postretirement Benefits - introduced requirements of disclosure of the composition of pension assets in addition to reporting the expected rate of return. When both expected rate of return and portfolio assets allocations are reported, it is harder for managers to justify expected returns assumptions that would be unrealistic given the asset portfolio composition (Komissarov, 2010). Komissarov (2010) shows that the degree of inconsistency between the expected rates of return and asset allocations declined following the adaptation of SFAS 132(R).

Given the extended use of unjustified high discount rates accounting standard setters have imposed the use of actual returns on assets instead of expected rates of returns. Opponents of this approach argue that this undermines the raison d'etre of pension fund investments, namely, to offer high average returns for when employees retire. This can imply long investment horizons which, depending on the age of the employee, can extend to 40 years (if the employee is 25 and retires at 65 ). The use of high expected returns is justified by managers as having high expectations with respect to the long-term performance of their investments. Moreover, they argue that these expectations can give insight into what are the performance targets and whether or not management is able to achieve these targets; actual returns are indicative of the investment goal of the sponsoring company and the degree with which the investment goal was fulfilled is given by the expected rate of return (Carpenter, 2007).

In using actual returns, long-term investments are judged over a short period of time. The frequently changing actual returns cause volatility of pension related expenses in the profits reported by companies. Consequently, actual returns put the noise of the markets in the accounts of the company and this can misguide decision makers and have further economic consequences (high retirement liabilities on the balance sheet of sponsoring companies can affect their lending capacities (Jones, 2011)). Almost 70 percent of the respondents (pension fund directors) of a 2010 National Association of Pension Funds (NAPF) Annual Survey cited by Clacher and Moizer (2011, p. 15) agreed that "the snapshot method of accounting - valuing assets according to today's market values - is inappropriate for long-term products such as pensions and generates too much volatility in the scheme valuation”. But Bader and Gold (2002, p.12) contradict this by arguing that "volatility is a property of markets; it is not a disease for which accounting is the cure". According to Adams et al. (2011) the choice between different asset growth rates is twofold and reflects the trade-off between relevance and reliability. Actual rates of return can be used if the scope is to obtain more reliable but less relevant financial statements. If on the other hand, expected rates of return are used then the financial statements will be more relevant but less reliable.

\subsection{Unique Interest Rate}

The new revised version of IAS19 suggests that pension funds will have to use one interest rate to obtain the net interest cost. That is, pension funds expect to make payments in the future and these cash flows are discounted with an interest rate. But pension funds also make investments and expect to receive cash flows that will grow, not with an expected rate of return but with the same interest rate as that used to discount liabilities. This allows for a net cost to be determined by subtracting the earnings obtained on assets from the expenses made with the liabilities.

In a simple scenario, $€ 1000000$ worth of assets invested at an expected return of $5 \%$ will grow in 10 years to $€ 1$ 630000 . If the projected liability for the same period is $€ 1480000$ and the actuarial discount rate is $4 \%$, the present value of the liabilities will be exactly $€ 1000000$ with no effect on the surplus (assets minus liabilities) of the company as the liability and the assets exactly cancel out. Liabilities are determined following a time path of first looking into the future and discounting to arrive at the present value; assets on the other hand follow a time path of incremental growth. In a hypothetical case and for ease of comparability, the assets are assumed to follow the same time path as liabilities: assuming end values as known and discounting to determine the present value. If the investments are expected to be worth $€ 1630000$ in 10 years and the same discount rate of $4 \%$ as that used for liabilities is applied to find the present value, then the assets are worth $€ 1100000$ instead of $€ 1000$ 000. A surplus of $€ 100000$ is artificially created because the discount rate is $4 \%$ instead of $5 \%$. This is caused by the fact that the discount rate used for investments did not take into account that investments are more risky than pension liabilities that in a pure DB setting are considered risk free (more risky investments should be discounted 
more heavily). So although not intended, the revised version of IAS 19 creates a difference in treatment between assets and liabilities: the liabilities are allowed to include expectations (through the actuarial assumptions made in determining the value of the projected liabilities) while the assets are assumed to grow in a deterministic manner (expected rates of return for assets are replaced by currently known interest rates). This makes assets and liabilities incomparable and a net interest income (interest cost minus asset growth) calculation unreliable. Furthermore, if accounting standards impose the use of the same interest rate for assets and liabilities, then it should not matter anymore if the investments are shared between stocks and fixed instruments as both will grow with the same rate in the profit and loss account of the company sponsoring DBs (although any extra return can be recognized in the other comprehensive income).

In proposing such changes, standard setters do not follow the logical path: first there is the contract between the company and the employees that dictates the worthiness of the liabilities (likelihood that the liabilities are going to be paid) and after deciding on the liabilities the investments are chosen in order to sustain the payment of those liabilities. The investments should be made such that they match liabilities but unless the assets completely mimic the liabilities, which is highly improbable, then they should not be considered under the same interest rate regime. Imposing the same interest rate for assets and liabilities can take away management incentives to find optimal portfolios.

\subsection{Recognition versus Disclosure}

Because pension accounting regulations asked for more transparency from sponsoring companies, pension obligations were transferred from the footnotes into companies' accounts. Fried (2010) provides empirical evidence of a negative stock price reaction around the release of SFAS 158 exposure draft as this standard proposed reallocation of already disclosed information from the financial statements footnotes to the balance sheet. Furthermore, the study identifies increased lobbying from managers of pension plans sponsoring companies against the implementation of SFAS 158 but does not continue to investigate whether or not lobbying had an effect on the measure of neutrality of the standard.

Sun (2011) also questions the effect of recognition versus disclosure of pension related information looking at economic consequences in terms of market responses. According to the study, analysts interpret differently disclosed and recognized information and recognition increases the markets perceived equity risk and leads to a higher cost of capital.

Pension plans' assets grow with an expected return determined from actuarial assumptions on long-term rates of return on government bonds and suitable risk premiums that take into account historic and expected market trends; any difference between the expected return on assets and the actual return is recognized in the statement of comprehensive income. So under the current pension accounting, actual returns are used but they impact the equity and not the profit and loss account. It should not matter if expected instead of actual returns are used to diminish the pension expenses. But using actual rates of return in the profit and loss account is expected to impact the performance of sponsoring companies (E\&Y) as uses of accounting information filter differently profit and loss account information and other comprehensive income information.

\section{Different Asset Allocation}

If pension funds invest in fixed income instruments then, as fair valuation requires searching for the correct discount rate in the market, both assets and liabilities can be affected by movements in the interest rates. Discounting fixed income assets and liabilities with a lower interest rate can have a positive impact on pension funds through the asset side, increasing the value of the assets but a negative impact through the liabilities side, increasing the value of the liabilities. This sensitivity of pension funds' assets and liabilities to interest rate movements is classified as an interest rate risk and a broadly used method of measuring this risk is the duration gap analysis. The concept of duration is used to provide an approximation of the sensitivity of a security's market value to a change in the interest rate (i.e., the percentage change in the price of a security for a unit change in the yield). As a rule of the thumb, when a company has fixed income instruments with duration of 5 years and liabilities with duration of 15 years, an increase of $1 \%$ in the interest rate leads to a $5 \%$ increase in the assets and a $15 \%$ increase in the liabilities. Thus, abrupt changes in the interest rate can make overnight pension plans insufficiently funded.

Pension funds apply strategies like asset-liability management (ALM) in an attempt to match the duration of the assets with that of the liabilities. This matching can lead to investing a high proportion in assets with a long duration (i.e., long-term bonds). Amir, Guan and Oswald (2010) and Mashruwala (2008) provide empirical evidence that UK companies, on average, shifted pension assets from equity to debt securities due to new pension accounting regulations (e.g., FRS 17). Chuk (2012) also finds that due to recognition requirements of 
SFAS 158, sponsoring companies increase the asset allocation to high-risk securities simultaneously reducing the expected rate of return. But this abrupt reallocation of assets from equity to debt instruments can be problematic. A high demand of bonds can drive prices up and yields down, increasing the present value of the liabilities so that more debt instruments will be needed to match the liabilities (Clacher \& Moizer, 2011). Too rigorous accounting regulations with respect to interest rates and recognition of total pension surplus/deficit (assets minus liabilities) on the balance sheet can impact the asset allocations of corporate pension funds and dampen the good things that pensions funds were credited for, i.e., development of capital markets (Jörg \& Niggemann, 2010).

Differently, Komissarov (2010) finds that in order to justify higher expected returns, US sponsoring companies increase the equity exposure. Kiosse and Peasnell (2009) document that requirements made on discount rates have impacted the reconfiguration of the asset allocation in favor of fixed interest securities irrespective if this would be the optimal investment.

\section{Risk Shifting}

As it is in the case of DBs, sponsoring companies guarantee the final benefit and therefore bear the risks inherent to pension funds including longevity risk, interest rate risk, inflation risk, investment return risk but also regulatory risks. That is, if there is underfunding of the pension plan, sponsoring companies may be asked to allocate money to restore the funding to an acceptable level. Although difficult to attribute solely to pension accounting, several studies (Broadbent, Palumbo, \& Woodman, 2006) document a causal relation between pension accounting and the shift from DB to DC schemes. Most of the studies analyze the pension market of US and UK as these two countries experienced the most notable changes between the years 2001-2011 (The P\&I/Towards Watson 300). Campbell, Dhaliwal and Schwartz (2010) provide empirical evidence that companies with high SFAS 158 incremental liabilities (alongside lower profitability, and lower growth opportunities) chose to freeze or terminate their defined benefit pension plans.

This DBs-DCs switch is anticipated to be detrimental to pension plan participants in the long run. Ramaswamy (2012) shows that in the UK the total contribution to DCs is around $9 \%$ of salaries compared to $20 \%$ of salaries for DBs. Employees with low financial expertise and who are therefore prone to behavioral bias may act in a myopic way and delay saving for retirement. This can lead to an insufficient retirement revenue and worse, pauperism in society. Therefore, the changes made to pension accounting do not support the continuation of the DB structures that used to be predominant in the pension environment and an important economic consequence can be that pension plan participants are harmed in the long run.

Also, in their attempt to hedge against as much risk as possible, DBs might see derivatives as tempting investment choices. In November 2010 the Committee on the Global Financial System (CGFS), part of the Bank for International Settlements, delegated a working group to look into how insurance companies and pension funds will be affected by forthcoming accounting and regulatory changes. CGFS considered that financial institutions face a double threat: low-interest rates and changing accounting regulations. The report reiterates what previous literature already documented in that future regulatory changes could lead to reallocations of investments across financial instruments but adds a twist: the report anticipates a notable increase in the use of derivatives. Greenwood and Vayanos (2008) show that DBs acquired a high volume of interest rate swaps in the period 2005-2006 in order to increase the duration of the pension fund assets.

The use of derivatives can increase especially for DBs as these plans have more levers to handle risk. DBs can transfer risks between generations through the so called intergenerational risk sharing. Namely, risks that affect an entire generation like labor market or capital market shocks can be transferred to other generations by adjustments to contributions or benefits. In typical DC structures most of the risks are born by pension plan participants. DCs shelter individual accounts where "what you put in" equals "what you get out". Individual participants and not companies decide on the proper investment strategy and implicitly on how much risk to bear. Besides not having the advantage of intergenerational risk sharing (like DBs), participants might have difficulty in understanding different types of derivatives and opt for a reduced exposure to such instruments. But the situation in which risks are transmitted entirely to pension plan participants is specific for pure DCs that have no solvency risk as the plan's liabilities are given by the value of the assets. Nevertheless, solvency requirements have to be met even in the case of DC plans if they have to guarantee minimum rates of return, minimum pensions corresponding to the amount saved by participants, rates of return within a range of returns relative to other pension funds in the market (Daykin, 2002). Therefore, in order to reduce risks, DCs stakeholders can actively influence the asset allocation strategy towards more investments in derivatives. Although derivatives have been tainted by a bad reputation they can have improved results of pension funds by hedging against 
various risks. Accounting can reinforce the transparency of risk management strategies so that the usage of derivatives can be properly understood by stakeholders.

\section{Conclusion}

Due to the transformations of pension accounting (fair valuation and requirements on balance sheets of sponsoring companies to include retirement assets and liabilities), the declining equity and interest rates are shown in the accounts of sponsoring companies. Thus, the assets have a lower value while the liabilities, discounted with lower interest rates, are higher. This results into many pension funds being underfunded due to changing accounting policies. The immediate economic consequences of these changed accounting policies are increases in contribution rates, cuts in benefits and partial instead of full indexation. This paper identifies other economic consequences that can be attributed to specific harmed parties (Table 2).

Table 2. Economic consequences and impacted parties

\begin{tabular}{ll}
\hline Economic consequences & Impacted party \\
\hline Earnings per share & Shareholders \\
Stock prices & Shareholders \\
Asset allocation & Shareholders \& Pension plan participants \\
Risk shifting & Pension plan participants \\
\hline
\end{tabular}

Research has documented that sponsoring companies with high pension liabilities experience declining earnings per share and stock prices. These economic consequences affect primarily the shareholders of the sponsoring company. Changes in pension accounting also impact the pension funds asset allocations. In the attempt of matching the duration of the liabilities, DBs tilt the portfolio towards more fixed income instruments harming the firms in need of capital. In the long run, institutional investors that invest mostly in debt instruments can damp the economic development of a country and have negative economic consequences for both shareholders and pension plan participants. In order to protect shareholders from negative economic consequences DBs sponsoring companies can opt to freeze the defined benefit structure and offer instead a defined contribution option. Under a defined benefit format the sponsoring company is responsible for the retirement revenue of its employees and in order to achieve the wanted pension revenue the contributions paid while working can be increased. Differently, in the case of defined contributions employees are uniquely responsible for how their savings are invested. Aside from a lack of financial knowledge individuals are prone to behavioral biases that make them unaware of the amount necessary to save for retirement. So on the long run, the DB-DC shift can be detrimental to pension plan participants.

Using only quantitative data can be misleading in identifying causality between DBs-DCs shifts and accounting changes because of the lack of clear quantitative indicators. Ratios between pension costs and pension liabilities or service cost and pension liabilities have been used to find the maturity of the pension fund but they do not provide the status of the pension fund. On the other hand, by using a qualitative approach a clear causality can be identified. As an example, in 2010 Boeing announced that in 2011 DB schemes will be frozen for newly hired employees. In 2012 Boeing justifies the decrease in their earnings per share by the retirement of the first wave of workers from the baby boom generation pension. Hence, further research can add a qualitative aspect to the research into pension accounting economic consequences improving the understanding of the phenomenon. This paper is a review of the literature accompanied by simple examples meant to clarify the most common pension accounting concepts. As pensions are long term products and as changes to pension accounting are relatively recent the realization of economic consequences is difficult to verify empirically.

Although meant to be neutral, accounting for pensions has become more conservative by requiring the use of the same interest rate for assets and liabilities. Apart from creating an artificial image that assets mimic perfectly the pension liabilities, this form of pension accounting places emphasis on the short term rather than on the long term perspective and pension funds' investments are meant to satisfy long term investments. Economic consequences that stem from conservative rather that neutral accounting policies should be incorporated by regulators in the standard setting process.

\section{Acknowledgements}

This work was supported by DoEsEc project - "Doctoral Studies in Economy at European Knowledge Standards", co-funded by European Social Fund through the Sectorial Operational Programme for Human Resources Development 2007 - 2013, and coordinated by The Bucharest Academy of Economic Studies. 


\section{References}

Adams, B., Frank, M. M., \& Perry, T. (2011). The Potential for Inflating Earnings through the Expected Rate of Return on Defined Benefit Pension Plan Assets. Accounting Horizons, 25(3), 443-464. http://dx.doi.org/10.2308/acch-10115

Amir, E., Guan, Y., \& Oswald, D. (2010). The effect of pension accounting on corporate pension asset allocation. Review of Accounting Studies, 15(2), 345-366. http://dx.doi.org/10.1007/s11142-009-9102-y

Bader, L. N., \& Gold, J. (2002). Reinventing pension actuarial science. Pension Forum, 14(2). Pension Section of the Society of Actuaries.

Blome, S., Fachinger, K., Franzen, D., Scheuenstuhl, G., \& Yermo, J. (2007). Pension Fund Regulation and Risk Management: Results from an ALM Optimisation Exercise. OECD Working Papers on Insurance and Private Pensions, No. 8.

Broadbent, J., Palumbo, M., \& Woodman, E. (2006). The Shift from Defined Benefit to Defined Contribution Pension Plans - Implications for Asset Allocation and Risk Management. Paper prepared for the working group on Institutional Investors, Global Savings and Asset Allocation established by the Committee on the Global Financial System, Bank for International Settlements, Basel.

Campbell, J., Dhaliwal, D. S., \& Schawartz, Jr. W. C. (2010). Equity Valuation Effects of the Pension Protection Act of 2006. Contemporary Accounting Research, 27(2), 469-536. http://dx.doi.org/10.1111/j.1911-3846.2010.01023_3.x

Carpenter, B. W., \& Mahoney, D. P. (2004). Toward the Goal of Teaching Excellence in Accounting: Reexamining the Role of Neutrality and Conservatism in the Development of Pension Accounting Standards. Journal of College Teaching \& Learning, 1(9), 57-64.

Carpenter, B. W., \& Mahoney, D. P. (2007). Accounting for defined benefit pension plans: is FASB finally fulfilling its 25 year old promise? Journal of Business \& Economics Research, 5(8), 79-90.

Chuk, E. (2012). Economic Consequences of Mandated Accounting Disclosure: Evidence from Pension Accounting Standards. http://dx.doi.org/10.2139/ssrn.1737543

Clacher, I., \& Moizer, P. (2011). Accounting for Pensions. Leeds University Business School. Retrived from http://www.napf.co.uk/PressCentre/NAPFcomment/ /media/Policy/Documents/0190_\%20Accounting_for_Pens ionsL.ashx

Committee on the Global Financial System Papers No 44. (2011). Fixed income strategies of insurance companies and pension funds. Bank for International Settlements.

Daykin, C. D. (2002). Risk management and regulation of defined contribution schemes. Seminar for Social Security Actuaries and Statisticians: Actuarial Aspects of Pension Reform, Moscow, Russian Federation. Retrieved from http://www.actuaries.org/PBSS/Documents/Moscow_Daykin_en.pdf

Deloitte. (2011). IAS 19-Employee Benefits. A closer look at the amendments made by IAS 19R. Retrieved from http://www.deloitte.com/assets/Dcom-Netherlands/Local\%20Assets/Documents/NL/Diensten/Accountancy /nl_nl_accountancy_brochure_IAS19_pensioen.pdf

Ernst, \& Young. (2011). Implementing the 2011 revisions to employee benefits. Retrieved from http://www.ey.com/Publication/vwLUAssets/Applying_IFRS:_IAS_19_Employee_Benefits/\$FILE/Applyi ng\%20IAS\%2019\%20Revisions\%20for\%20employee\%20benefits.pdf

Fried, A. N. (2010). The Economic Consequences of SFAS No. 158. http://dx.doi.org/10.2139/ssrn.1579539

Greenwood, R., \& Vayanos, D. (2010). Bond Supply and Excess Bond Returns. CEPR Discussion Paper No. DP6694. Available at SSRN: http://ssrn.com/abstract=1141016

Houmes, R., \& Boylan, B. (2010). Has the adaptation of SFAS 158 caused firms to underestimate pension liability? A preliminary study of the financial reporting impact of SFAS 158. Academy of Accounting and Financial Studies Journal, 14(4), 55-66.

Jones, D. A. (2011). Changes in the Funded Status of Retirement Plans after the Adoption of SFAS No. 158: Economic Improvement or Balance Sheet Management?. Under review at Contemporary Accounting Research.

Jörg, R., \& Niggemann, T. (2010). Pension Funding and Capital Market Development. Available at http://dx.doi.org/10.2139/ssrn.1571126 
Kiosse, P. V., \& Peasnell, K. (2009). Have changes in pension accounting changed pension provision?. A review of the evidence. Accounting and Business Research, 39(3), 255-267. http://dx.doi.org/10.1080/00014788.2009.9663365

Komissarov, S. (2010). Accounting for pensions: Measurement neutrality and the effects of Statement No. 132(R) and No. 158. The University of Wisconsin-Madison.

Mashruwala, S. D. (2008). Does Smoothing in Pension Accounting Encourage Equity Investment in Corporate Pension Plans? Evidence from the U.K. http://dx.doi.org/10.2139/ssrn.1405494

Napier, C. J. (2009). The logic of pension accounting. Accounting and Business Research, 39(3), 231-249. http://dx.doi.org/10.1080/00014788.2009.9663363

Ramaswamy, S. (2012). The Sustainability of Pension Schemes. BIS Working Paper No. 368. http://dx.doi.org/10.2139/ssrn.1980094

Sun, F. (2011). Economic consequences of SFAS 158 (Ph.D. dissertation). Temple University.

Towers Watson. (2011). P\&I/TW Top 300 Pension Funds. Available at http://www.towerswatson.com/assets/pdf/5351/TW-PI-300.pdf

Zeff, S. (1978). The rise of economic consequences. Journal of Accountancy, 146. 